\title{
HASTANEDE YATIŞ DÖNEMİNDE HASTALARIN AĞIZ-DİŞ SAĞLIĞININ DEĞERLENDİRİLMESİ
}

\author{
EVALUATION OF ORAL HEALTH OF PATIENTS UNDER HOSPITALIZATION \\ PERIOD
}

\author{
Dr. Öğr. Üyesi Zeliha Gonca BEK KÜRKLÜ $\quad$ Dr. Öğr. Üyesi Burcu EVLİCE* \\ Doç. Dr. Ahmet Turan EVLICE ${ }^{* * *}$
}

\author{
Makale Kodu/Article code: 4399 \\ Makale Gönderilme tarihi: 24.05.2020 \\ Kabul Tarihi: 06.10 .2020 \\ DOI : $10.17567 /$ ataunidfd. 806441
}

Z.Gonca Bek Kürklü : ORCID ID: 0000-0002-4726-7883

Burcu Evlice: ORCID ID: 0000-0003-3384-0092

Ahmet Turan Evlice: ORCID ID: 0000-0002-4451-9475

\section{Öz}

Amaç: Hastanede yatış, diş fırçalama gibi rutin hale gelmiş ola... n................................

günlük hastaneye yatışın hastaların ağız-diş sağlığı durumuna etkisini değerlendirmektir.

Gereç ve Yöntem: Bu çalışma, yatan hastalarda yapılan gözlemsel bir çalışmadır. Başlangıçta (hastaneye yatışının ilk 24 saati) ve 7. günde Plak indeksi (PI) ve tükürük S. mutans seviyesi ölçüldü. Çalışmaya ardışık yedi günden fazla süre yatacak olan 20 hasta dahil edildi.

Bulgular: Yirmi hastanın başlangıçta medyan PI'i 1.5(0;3) iken 7. Günde medyan PI $2.0(0 ; 3)$ 'dür $(p=0.005)$. Başlangıçta yüksek S. mutans seviyesine sahip hastaların oranı (>5x $105 \mathrm{CFU} / \mathrm{mL}) \% 50$ iken 7 . Günde bu oran \%20 artarak \%70'e yükselmiştir $(p=0.333)$.

Sonuç: PI ve tükürük S. mutans seviyesi ile değerlendirilen ağız-diş sağlığı, 7 gün hastanede yatış süresinde kötüleşti.

Anahtar kelimeler: Dental plak indeksi, Streptokokus mutans, Yataklı tedavi

\section{ABSTRACT}

Aim: Hospitalization period may change oral hygiene habits that have become routine like brushing teeth. The aim of this study to evaluate the oral health status of hospitalized patients because of changing routine oral health habits in days of staying hospital.

Material and Methods: This is an observational study in patients. Plaque index (PI) and saliva S. mutans level at baseline (first 24 hours of hospitalization) and on day 7 was measured to evaluate if there are some retrogression of oral health status. Twenty patients who were hospitalized for more than seven consecutive days were included in the study.

Results: The median PI of 20 patients at baseline was 1.5( $0 ; 3)$ and on Day 7 the median value was $2.0(0 ; 3)(p=0.005)$. While the proportion of patients with a high level of S.mutans (> 5x 105 CFUmL) was $50 \%$ at baseline, on the 7 th day, this rate increased by $20 \%$ to $70 \%(p=0.333)$.

Conclusion: Oral health, assessed through PI and saliva S. mutans level deteriorated during 7 day hospitalization, and coused significant retrogression of oral health status.

Key words: Dental Plaque Index, Hospitalization, Streptococcus mutans

Çukurova Üniversitesi, Diş Hekimliği Fakültesi, Restoratif Diş Tedavisi AD, Adana.

${ }^{*}$ Çukurova Üniversitesi, Diş Hekimliği Fakültesi, Ağız, Diş ve Çene Radyolojisi AD, Adana.

*cukurova Üniversitesi, Tıp Fakültesi, Nöroloji AD, Adana.

Kaynakça Bilgisi: Bek Kürklü ZG, Evlice B, Evlice AT. Hastanede yatış döneminde hastaların ağız-diş sağlı̆ının değerlendirilmesi. Atatürk Üniv Diş Hek Fak Derg 2021; 31: 8-14.

Citation Information: Bek Kurklu ZG, Evlice B, Evlice AT. Evaluation of oral health of patients under hospitalization period. J Dent Fac Atatürk Uni 2021; 31: 8-14.

\section{GİRİş}

Hastanede yatış, ağrı ve rahatsızıı̆ın yarattığ stres ve endişe bireyin normal günlük alışkanlığını değiştirir. ${ }^{1}$ Aynı zamanda hastalarda benlik saygısında azalma gözlenir ve kendi bakımlarını alışııları şekli ile yapmayı ihmal ederler. Diş fırçalama gibi rutin hale gelmiş olan ağız hijyeni alışkanlıklarını yerine getirme motivasyonunu kaybederler. ${ }^{2}$ Hastalık, ilaçlar ve diyetteki fark- Iılaşmalar ağız florasını değiştirir. Hastadaki fiziksel bir kısıtlama veya hastane ortamındaki kısıtIılıklar normal yaşantıda düzenli gerçekleştirilen ağızdiş sağlı̆ı alışkanlıkların yerine getirilmesini engellemesi veya güçleştirmesi ile mevcut hastalık senaryosu daha da kötüleşir. ${ }^{3}$ 
Hastaneye yatış veya fonksiyonel gerileme nedeniyle diş fırçalamadaki yetersizlik diş üzerinde oluşan plağın mekanik olarak uzaklaştırılamamasına neden olabilir. Ağız sağlındaki bu yetersiz genellikle plak birikimi içinde yer alan bakteri sayısında artışa neden olur. ${ }^{4}$ Dental plaktaki patojenik mikroorganizmalar, organların ve sistemlerin işlevlerini tehlikeye atan, artan morbidite ve mortaliteye katkıda bulunan enfeksiyöz ve/veya enflamatuar süreçlerde önemli bir rol oynamaktadır. ${ }^{5}$

Diş çürüğü ve periodontal hastalık oluşmadan önce meydana gelen dental plakta 500 den fazla bakteri türü tespit edilmiştir. ${ }^{6-11}$

Bu oluşan bakterilerden Streptococcus mutans, oral kavitetede yaygın olarak bulunan bir Gram pozitif, hareketsiz, katalaz negatif, fakültatif anaerobik ve bilinen en önemli karyojenik bakteridir. Bu bakteriler mono ve disakkaritleri fermente eder ve laktik ve asetik asit üretirler. Oluşan bu asit diş sert dokularında çözünmelere sebep olur. ${ }^{12-15}$

Yapılan araştırmalarda diş çürüğü ile ağız içindeki S. mutans düzeyi arasında pozitif bir ilişki bildirilmiştir. ${ }^{16-18}$

Tükürükte mevcut S. mutans seviyesi çürük riskini değerlendirmek amacıyla en sık kullanılan mikrobiyolojik parametrelerden biridir. Tükürükte Streptococcus mutans miktarının belirlenmesinde yeni ve geleneksel analiz yöntemleri mevcuttur. S. mutans seviyesi $>5 \times 10^{5} \mathrm{CFU} / \mathrm{mL}$ ise yüksek ve $<5 \times 10^{5} \mathrm{CFU} /$ $\mathrm{mL}$ ise düşük düzey olarak değerlendirilir. ${ }^{19}$

Çürük ve oral hijyen durumunun, farklı yaş, cinsiyet, sosyoekonomik durum, etnik köken / ırk, sistemik hastalıklar ve farklı topluluklarda değişkenlik gösterdiği belirtilmiştir. ${ }^{20-27}$

Fakat hastane koşulları ve hastaların hastanede kalışları sırasında ağız-diş sağlığında meydana gelen değişiklikleri tanımlayan bir çalışma yapılmamıştır.

Çalışmamızın amacı 7 gün kesintisiz hastanede yatan hastaların, ağız hijyeni alışkanlıklarındaki farklılaşma, plak indeksi ve tükürük S. mutans seviyesindeki değişim üzerinde hastanedeki yatışının etkisini değerlendirmektir.

Bu çalışmanın hipotezi, hastaları hastane yatış sürecinde oral hijyenin göstergeleri olan plak indeksinde ve çürük yapıcı mikroorganizma olan S. Mutansın seviyelerinde bir artış olmasıdır.

\section{GEREÇ VE YÖNTEM}

Bu çalışma protokolü Helsinki Bildirgesi'nin ilgili yönergelerine uygun olarak gerçekleştirilmiştir ve
Çukurova Üniversitesi Tıp Fakültesi Girişimsel Olmayan Klinik Araştırmalar Etik Kurulu, 04.09.2019 tarihli 73 karar numaralı raporu ile onaylanmıştır. Bilgilendirilmiş olur formları tüm katılımcılar tarafından imzalanmıştır.

Çalışmada Çukurova Üniversitesi Tıp Fakültesi nöroloji servisinde Ekim 2019-Aralık 2019 tarihleri arasında ardışık yedi günden fazla süre yatacak olan, 18-65 yaş aralığında, 20 hasta değerlendirildi. Diş fırçalamasını engelleyecek fiziksel kısıtlaması olan, dişsiz, şiddetli mental problemi olan, demans, alzeimer ve onam alınamayan hastalar çalışma dışı bırakıldı.

Her katıımcının demografik verileri, tıbbi sağlık öyküsüyle birlikte toplanmıştır. Toplanan diğer veriler: hastaneye yatmadan önce ve sonra rutin diş firçalama alışkanlıkları, tükürük S. mutans düzeyleri, plak indeksi değerleri ve ağız-diş sağlığı prosedürlerini uygulamadaki zorluklardır.

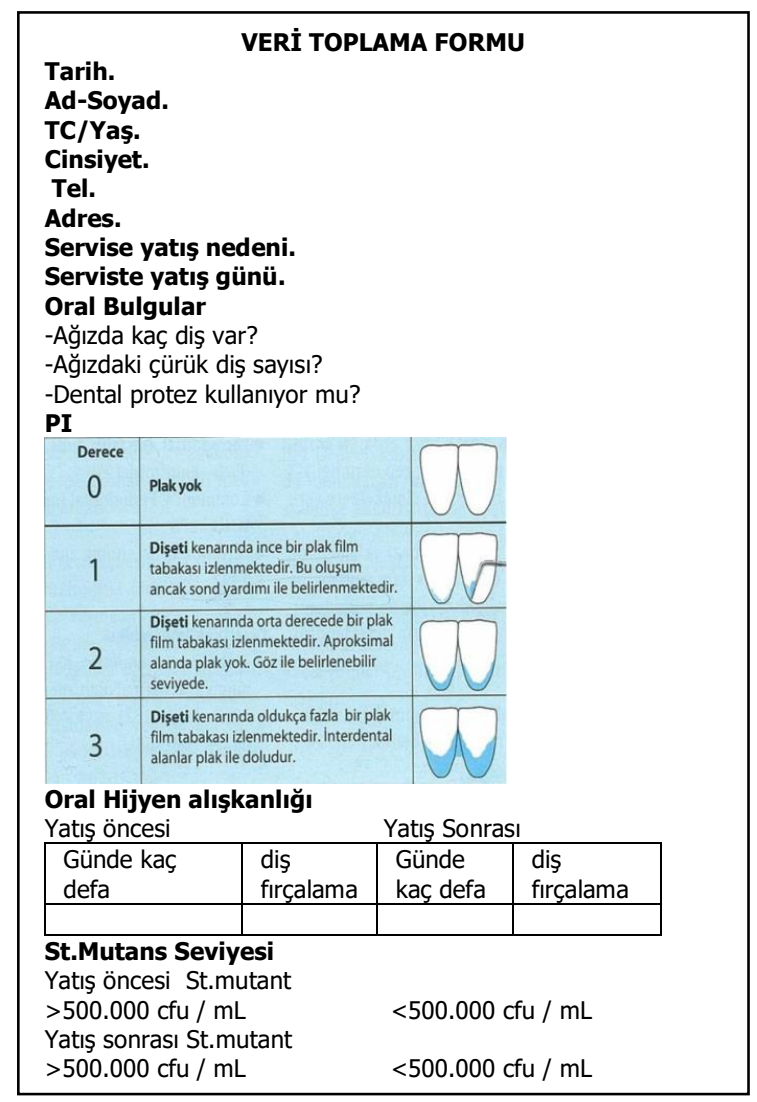

Çalışmaya katılan tüm bireylerin ağız içi muayenesi yapay aydınlatma (el feneri) altında oral ayna ve sond kullanılarak gerçekleştirildi. Klinik parametrelerin daha iyi görüntülenmesi için dişler gazlı bezle kurutuldu. Hastalar tercihen ağız boşluğunun görüntülenmesi kolay olacak şekilde yatakta yatarken incelendi. Değerlendirmeler tek bir diş hekimi tarafın- 
dan yapıldı-Muayene sırasında bir yardımcı feneri tuttu. Hastalara ağız-diş sağlığı durumları hakkında bilgi verilmedi ve ağız-diş sağlığı yönelimleri ile ilgili bir tavsiyede bulunulmadı.

$\mathrm{Bu}$ amaçla periodontal değerlendirme için, Silness ve Löe'nin Plak İndeksi (Pİ) ölçümü gerçekleştirildi. Plak İndeksi, dişlerde plak birikimini tanımlamak için uluslararası diş kliniklerinde en çok kullanılan sıfırdan üçe kadar değer alan dört puanlık bir ölçektir. 0 skoru plak olmadığını gösterir ve 3 skoru dişin büyük çoğunluğunun plakla kaplandığı anlamına gelir (Tablo 1).

Tablo 1. Silness ve Loe Plak İndeksi

\begin{tabular}{|l|l|}
\hline $\begin{array}{l}\text { Plak } \\
\text { Indeksi }\end{array}$ & Kriter \\
\hline 0 & Plak yok \\
\hline 1 & $\begin{array}{l}\text { Dişeti kenarında ince bir plak film tabakası. Göz } \\
\text { ile gözükmez ama sond yardımıyla kaldırılabilir }\end{array}$ \\
\hline 2 & Dişeti kenarında görülebilir plak tabakası \\
\hline 3 & Dişeti kenarında görülebilir kalın plak tabakası \\
\hline
\end{tabular}

Ayrıca hastalardan servise yattıkları ilk 24 saat içinde tükürük örnekleri alındı. Tükürük toplanmadan önce, katılımcılara dişlerini fırçalamamaları ve örneklemeden önce 1 saat boyunca yemek yemekten, içmekten, sigara içmekten sakınmaları istendi. Tükürük numunesi toplama işlemlerinin yemek saatlerinden 1 saat önce, $10: 00-11: 00$ veya $15: 00-16: 00$ saat aralığında alınmasına özen gösterildi. Hastaların tükürüğündeki S. mutans miktarı bir immünoanaliz sistemi olan SalivaCheck MUTANS (GC, Japonya) ile belirlendi. Katılımcılardan 3 dakika boyunca parafin çiğnemesi istendi.

Uyarılmış tükürük toplandı. $250 \mu \mathrm{L}$ 'lik bir tükürük örneği, 30 saniye boyunca $50 \mu \mathrm{L}$ Tris-NaOH (Reaktif-1) ile kuvvetli bir şekilde işlendi ve daha sonra pH'ı nötralize etmek için $100 \mu \mathrm{L}$ Tris-sitrat (Reaktif-2) ile karıştırıldı. Test cihazına $300 \mu \mathrm{L}$ işlenmiş tükürük örneği yerleştirildi. 15 dakika sonra test cihazında iki kırmızı çizgi görülmesi yüksek $S$. mutans seviyesi ( $>5 \mathrm{x}$ $10^{5} \mathrm{CFU} / \mathrm{mL}$ ), bir kırmızı çizgi görülmesi düşük $\mathrm{S}$. mutans seviyesi ( $<5 \times 10^{5} \mathrm{CFU} / \mathrm{mL}$ ) olarak sınıflandırıldı (Resim 1). En az 7 gün kesintisiz yatan hastadan 7. günün sonunda aynı yöntemle tekrar tükürük numunesi alınıp S. mutans seviyesi tespit edildi.

İstatistiksel analizler SPSS software version 23.0 (IBM, Armonk, NY, ABD) Paket Programı ile yapıldı. Araştırmada elde edilen veriler kategorik veri olduğu için nonparametrik istatistikler kullanıldı. HastaIarın cinsiyeti, yaşı, ağızdaki toplam diş sayısı ve ağız- daki çürük diş sayısı, dental plak indeksi, günlük fırçalama alışkanlıkları, hastaneye yatış nedenleri ve $\mathrm{S}$. mutans seviyeleri için tanımlayıcı istatistikler (yüzde, medyan, minimum, maksimum, ortalama ve standart sapma) şeklinde ifade edildi. Bir ve 7. gündeki plak indekslerinde medyan gelen değişimin ve $S$. mutans seviyelerinin anlamlı bir şekilde farklılık gösterip göstermediğini test için Wilcoxon sıra sayıları işaret (Wilcoxon signed rank test) testi kullanıldı. Bir ve 7. Gündeki günlük fırçalama alışkanlığı oranı arasındaki farkın önemliliğini test için Fisher kesin olasılık testi kullanıldı.

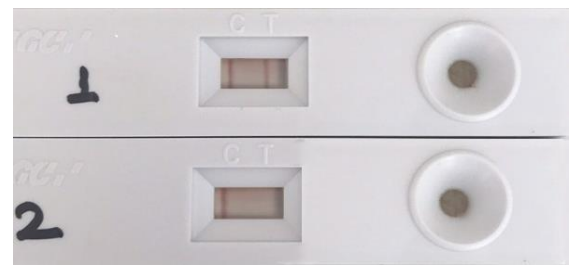

Resim 1. 15 dakika sonra Saliva-Check MUTANS test sonucu

\section{BULGULAR}

Bu çalışmaya, Nöroloji servisinde kesintisiz en az 7 gün yatan yaş ortalaması $48.9 \pm 10.8$ olan 14 (\%70) erkek ve $6(\% 30)$ kadın hasta dahil edildi (Tablo 2 ).

Hastalardaki ağızda bulunan ortalama diş sayısı $21.1 \pm 8.1$ (maksimum 29 diş, minimum 2 diş)'

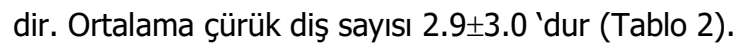

Hastaların servise yatış nedenleri çok değişiktir, nedenlerine göre frekans dağılımları yüzde olarak verildi (Tablo 3).

Hastaların servise yattıkları 1. gün medyan plak indeksi $1.5(0 ; 3)^{\prime}$ dür ve 7 . günde medyan $2.0(0 ; 3)^{\prime}$ e yükselmiştir. 1. ve 7. günde plak indekslerindeki fark istatistiksel olarak anlamlıdır $(p=0.005)$ (Tablo 4).

Hastaların günlük diş fırçalama oranı 1. günde $\% 55$ iken yedinci günde \%15'e düşmüştür, düşme oranı \%40' dır ( $p=0.019)$ (Tablo 4). Sekiz kişi ilk günü fırçalarken 7. Günde fırçalamayacak şekilde alışkanlığını değiştirmiş̧tir. Hastaların \% 40'ının günlük diş fırçalama sıklığını azaltmasına rağmen,\% 60'ı hastaneye yatış sırasında diş fırçalamanın uygulanmasını engelleyen bir fiziksel sorun bildirmemiştir (Tablo 5).

Birinci gün yüksek $\mathrm{S}$. mutans seviyesine sahip hastaların oranı ( $>5 \times 10^{5} \mathrm{CFU} / \mathrm{mL}$ ) \%50 iken 7. Günde bu oran \%20 artarak \%70'e yükselmiştir $(p=0.333)$ (Tablo 4). 
BEK KÜRKLÜ, EVLİCE,

EVLICE

\section{TARTIŞMA}

Tablo 2. Örneklemin demografik ve dental özellikleri

\begin{tabular}{|c|c|c|c|c|c|}
\hline Değişken & & $\mathrm{N}$ & Ortalama \pm SS & $\begin{array}{c}\text { Medyan } \\
\text { (Min,Mak.) }\end{array}$ & $\%$ \\
\hline \multirow[t]{3}{*}{ Cinsiyet } & $\mathrm{K}$ & 6 & & & 30 \\
\hline & $\mathrm{E}$ & 14 & & & 70 \\
\hline & Genel & 20 & & & 100 \\
\hline \multirow[t]{3}{*}{ Yaş } & $\mathrm{K}$ & 6 & $46.3 \pm 8.9$ & $45.5(35.0 ; 58.0)$ & \\
\hline & $\mathrm{E}$ & 14 & $47.1 \pm 11.8$ & $48.0(24.0 ; 65.0)$ & \\
\hline & Genel & 20 & $48.9 \pm 10.8$ & 47.5(24.0;65.0) & \\
\hline \multirow[t]{3}{*}{ Diş sayısı } & $\mathrm{K}$ & 6 & $21.2 \pm 7.5$ & $24.0(7.0 ; 28.0)$ & \\
\hline & $E$ & 14 & $21.0 \pm 8.6$ & $24.0(2.0 ; 29.0)$ & \\
\hline & Genel & 20 & $21.1 \pm 8.1$ & $24.0(2.0 ; 29.0)$ & \\
\hline \multirow{3}{*}{$\begin{array}{c}\text { Çürük } \\
\text { diş sayısı }\end{array}$} & $\mathrm{K}$ & 6 & $2.8 \pm 2.0$ & $2.5(0.0 ; 6.0)$ & \\
\hline & $E$ & 14 & $2.9 \pm 3.4$ & $2.5(0.0 ; 12.0)$ & \\
\hline & Genel & 20 & $2.9 \pm 3.0$ & $2.5(0.0 ; 12.0)$ & \\
\hline
\end{tabular}

Tablo 3. Örneklemin hastaneye yatış nedenleri

\begin{tabular}{|l|l|l|}
\hline Hastalık adı & $\mathbf{n}$ & $\mathbf{\%}$ \\
\hline Müsküler distrofi & 4 & 20,0 \\
\hline Baş ağrısı & 4 & 20,0 \\
\hline Ateş & 3 & 15,0 \\
\hline Miyelit & 1 & 5,0 \\
\hline Görme bozukluğu & 1 & 5,0 \\
\hline Nöropati & 3 & 15,0 \\
\hline Miyastenia gravis & 1 & 5,0 \\
\hline Epilepsi & 2 & 10,0 \\
\hline Multıble skleroz & 1 & 5,0 \\
\hline Genel & 20 & 100,0 \\
\hline
\end{tabular}

Tablo 4. Yatıştan önce ve 7 gün sonra plak indeksine, tükürük S. mutans seviyelerine ve diş fırçalama sıklığına göre dağılım

\begin{tabular}{|l|c|c|c|c|c|}
\hline & \multicolumn{2}{|c|}{ Başlangıç } & \multicolumn{2}{c|}{ 7. gün } & \multirow{2}{*}{ p değeri } \\
\cline { 2 - 5 } & Ort \pm SS & $\begin{array}{c}\text { Med } \\
\text { (min;mak) }\end{array}$ & Ort. \pm SS & $\begin{array}{c}\text { Med } \\
\text { (min;mak) }\end{array}$ & \\
\hline Plak indeksi & $1.6 \pm 0.8$ & $1.5(0 ; 3)$ & $2.0 \pm 0.8$ & $2.0(0 ; 3)$ & $\mathrm{p}=0.005$ \\
\hline Fırçalama & & $\%$ & & $\%$ & \\
\hline Var & 11 & $\mathbf{5 5}$ & 3 & $\mathbf{1 5}$ & $\mathrm{p}=0.019$ \\
\hline Yok & 9 & 45 & 17 & 85 & \\
\hline $\begin{array}{l}\text { S.mutans } \\
\text { seviyesi }\end{array}$ & & $\%$ & & $\%$ & \\
\hline Düşük & 10 & $\mathbf{5 0}$ & 6 & $\mathbf{3 0}$ & $\mathrm{p}=0.333$ \\
\hline Yüksek & 10 & 50 & 14 & 70 & \\
\hline
\end{tabular}

Tablo 5. Hastanede yatış sırasında ağız hijyeni prosedürlerini engelleyen bariyer veya zorluğa göre örnek dağılımı

\begin{tabular}{|l|l|l|}
\hline Hastanedeki Fiziksel Engeller & $\mathrm{n}$ & $\%$ \\
\hline $\begin{array}{l}\text { Ağız hijyeni için yeterli yer eksikliği/Şahsi tuvaletin } \\
\text { yokluğu }\end{array}$ & 10 & 50 \\
\hline Fiziksel hareket kaybı & 2 & 10 \\
\hline Engel veya zorluk yok & 8 & 40 \\
\hline
\end{tabular}

Bu gözlemsel çalışmada, nöroloji servisinde kesintisiz 7 gün yatan hastaların ağız-diş sağlığı durumundaki değişimler değerlendirildi.

Çalışmamızda, yatan hastaların fırçalama alışkanlığında önemli bir düşüş, plak indeksi ve tükürük S. mutans seviyesinde önemli bir artış tespit edilmiştir.

Literatürde kendi ağız bakımını yapamayan hemşire bakımına muhtaç olan yoğun bakım ünitelerinde yatan, onkolojik ve nörolojik hastalar üzerinde yapılmış çalışmalar mevcuttur. ${ }^{28-31}$

$\mathrm{Bu}$ çalışma, diğer çalışmalardan farklı olarak, serviste yatan hastaları değerlendirdiği için literatürde böyle bir çalışma bulunmamaktadır.

Periodontal hastalıklar ve diş çürüğünü etkileyen faktörler arasında genetik, eğitim seviyesi, sosyoekonomik durum, hastalıklar, ilaçlar, beslenme alışkanıı̆ı, ağız hijyeni, diş fırçalama alışkanlığı sayılabilir. Hastanede yatan bakımlarını kendileri yapabilecek durumdaki hastalarda da yukarıda sayılan faktörlerden; hastalıklar, ilaçlar, beslenme alışkanlığı, ağız hijyeni ve diş fırçalama alışkanlığı gibi faktörler değişime uğramaktadır.

Ağız-diş sağlığı durumunun bozulmasının ilk olası nedeni diş fırçalama oranındaki azalmadır. Çalışmanın gösterdiği diğer bir husus da hastaneye yatırılan birçok hasta hastaneye yatmadan önce de günlük diş fırçalama sıklığını düşük bildirmiştir. Düşük diş fırçalama oranı, diş plağının birikmesine ve dolayısıyla PI deki artış sonucu dişeti iltihabının başlamasına veya artmasına buna bağlı olarak da S. mutans seviyesinin artışı sonucu geriye dönüşümsüz diş sert dokularında dekalsifikasyona neden olabilir.

PI artışlarına katkıda bulunmuş olabilecek diğer olası faktörler, önceden var olan ancak bildirimde bulunulmamış sistemik durumlar ve hastanede yatış döneminde ilaç kullanımıdır. Her iki faktör de oral ortamı ve konakçının yerleşik mikroorganizmaları ile normal simbiyotik ilişkisini değiştirme potansiyeline sahiptir. ${ }^{32}$ Ayrıca, hastaneye yatış sırasında stres, kaygı ve rahatsızlığın da ağız-diş sağlığı üzerinde olumsuz bir etkisi vardır. ${ }^{33}$

Yoğun bakım ünitesindeki hastaların 48 saatlik hastanede yatışından sonra, oral mikrobiyotlarının bileşiminde Gram-pozitif basillerin baskın çıktığı gösterilmiştir. ${ }^{34}$ Diğer taraftan normal dental plak da bu bakteriler için doğal bir rezervuar görevi görecektir.

Yoğun bakım ünitesinde yatan hastalarda plak indeksleri 72 saat sonunda istatistiksel olarak anlamlı 
artış göstermiştir ve hastanede kalış süresi arttıkça plak indeksi de artmıştır. ${ }^{35} \mathrm{Bu}$ çalışmanın sonuçları bizim çalışmamızla benzerlik göstermektedir.

Çalışmanın ortaya koyduğu bir başka bulgu ise, katılımcıların büyük bir kısmı, her zamanki ağız-diş sağlığı prosedürlerini uygulamalarını engelleyen bir dış engel bildirmemiştir. Hastanede şahsi tuvalet sağlanamaması veya yetersiz fiziksel altyapı gibi bazı kısıtlar ağız-diş sağlığı bakım prosedürlerinin uygulanmasını zorlaştırabilir ama alışkanlıkları terk etmelerini gerektirmez. Günlük diş fırçalama sıklığındaki azalmanın önemli nedeninin sağlık sorunları hakkında endişe duyan hastaların psikolojik faktörlerinden dolayı alışkanlığını terk etmesi olarak görülebilir-

Bu çalışmada, hastaların normal yaşantılarında da ağız bakımına yeterli önemi vermediklerini ve yeterli zaman ayırmadıklarını göstermektedir. Buna ilaveten, hastane personel arasında ağız-diş sağlığı ile ilgili bilgi eksikliği, hemşirelerin yetersiz eğitimi ve bu kurumların hastalara uygun ağız hijyeni sağlamak için doğru ekipmana sahip olmamaları hastanelerde ağızdiş sağığı protokollerini uygulamayı daha da zorlaştırmaktadır.

Periodontal hastalıklar ve diş çürüğü, sistemik hastalığın başlaması riskini (risk faktörleri) veya mevcut hastalığın ilerlemesini (prognostik faktörler) etkileyen çok faktörlü karmaşık bir hastalıktır. Kötü ağız hijyeninin, düşük doğum kilo ağırlığı, obstrüktif akciğer hastalığı, koroner arter hastalığı, diyabet, inme, romatoid artrit, osteoporoz ve osteoartrit ile ilişkisi kanıtlanmıştır. ${ }^{36-40}$ Ayrıca dental patolojilerin ateş, baş ağrısı, sırt ve boyun ağrısı ile ilişkili olabileceği hatırlanmalıdır. ${ }^{41-43}$

Yoğun bakım ünitesinde, hastane kaynaklı pnömoninin en büyük sebeplerinden biri oral kolonizasyondur. Sağlıklı kişilerde \%10.0'un altında gramnegatif basillerle oral kolonizasyon görülürken, hastaneye yatıştan 48 saat sonra hastaların \%30- 40'ında kolonize olduğu, ağır ve kronik hastalığı bulunanlarda bu oranın \%70-75'lere çıkabildiği bildirilmektedir. ${ }^{44} \mathrm{Bu}$ nedenle etkin bir şekilde yapılacak olan ağız bakımı akciğerlere ulaşabilecek ve yerleşebilecek mikroorganizmaların sayısını azaltmak için çok önemlidir. ${ }^{45}$

Bir diş hekimi, yoğun bakım ünitelerinde ve serviste yatan hastaların ağız bakım protokollerini uygulayarak, bu tür faaliyetleri denetleyerek veya hemşirelik ekibine protokollerin uygulanmasında yardımcı olarak hastanenin profesyonel ekibiyle birlikte çalışabilir. Ağız-diş sağlığının teşviki, genel sağlığın iyileştirilmesinde önemli bir rol oynayabilir ve bu hastaların yaşam kalitesi üzerinde olumlu bir etkisi olabilir ${ }^{46}$.

\section{SONUÇ}

Hastanede yatan hastaların ağız-diş sağlığı ile ilgili alışkanlıkları terk etmeleri, plak indekslerindeki artış ve tükürüklerindeki $\mathrm{S}$. mutans düzeylerinin yükselişi ile hastaların 7 gün içinde ağız diş sağlığının bozulduğu belirlendi.

Ağız ve diş ortamı, sistemik hastalıklara sebep olabilecek çok çeşitli mikroorganizmaları barındııı. Bu nedenle sistemik hastalığın başlaması riskini veya mevcut hastalığın ilerlemesini azaltmak için üstünde önemle durulmalıdır.

Serviste yatan hastalar için ağız bakım protokollerinin uygulanması, hastaların ağız-diş sağlığı durumunun korunmasına veya iyileştirilmesine, genel sağlık kalitelerinin artmasına önemli katkıda bulunabilir.

NOT: Çalışmada herhangi bir yazar, kurum ya da kuruluş ile çıkar çatışması içerisinde bulunmamaktadır. Makale daha önce hiçbir yerde yayınlanmamış ve yayınlanmak üzere işlem görmemektedir

\section{KAYNAKLAR}

1- Delfini, ABL, Roque, AP, Peres RS. Anxious and depressive symptomatology among adults in patients: screening in clinical ward. Rev Interinst Psico 2009;2:12-22.

2- Carrilho Neto A, De Paula Ramos S, Sant'Ana AC, Passanezi E. Oral health status among hospitalized patients. Int J Dent Hyg 2011;9:21-9.

3- Zhu HW, McGrath C, McMillan AS, Li LSW. Can caregivers be used in assessing oral health-related quality of life among patients hospitalized for acute medical conditions? Community Dent Oral Epidemiol 2008;36:27-33.

4- Marsh PD. Dental plaque as a biofilm and a microbial community implications for health and disease. BMC Oral Health 2006;15(Suppl 1):S14.

5- Seneviratne CJ, Zhang CF, Samaranayake LP. Dental plaque biofilm in oral health and disease. Chin J Dent Res 2011;14:87-94.

6- Peterson SN, Snesrud E, Schork NJ, Bretz WA. Dental caries pathogenicity: a genomic and metagenomic perspective. Int Dent J 2011; 61:1122.

7- Huang R. Li M, Gregory RL. Bacterial interactions in dental biofilm. Virulence 2011;2:435-44. 
BEK KÜRKLÜ, EVLİCE,

8- Marsh PD. Dental plaque: biological significance of a biofilm and community life-style. J Clin Periodontol 2005;32(Suppl 6):S7-15.

9- Ritz HL. Microbial population shifts in developing human dental plaque. Arch Oral Biol 1967;12:1561-8.

10- Kuramitsu HK, He X, Lux R, Anderson MH, Shi W. Interspecies interactions within oral microbial communities. Microbiol Mol Biol Rev 2007;71:65370.

11- BJ Paster, SK. Boches, JL Galvin, RE Ericson, CN Lau, VA Levanos, A Sahasrabudhe, FE Dewhirst. Bacterial diversity in human subgingival plaque. J Bacteriol 2001;183:3770-83.

12- Loesche WJ. Role of Streptococcus mutans in human dental decay. Microbiol Rev 1986;50:35380.

13- Newburn E. Cariology, Chicago, Quintessence Publishing Co, 1989.

14- Nes IF, Diep DB, Holo H. Bacteriocin diversity in Streptococcus and Enterococcus. J Bacteriol 2007; 189:1189-98.

15- Ajdic D, Pham VT. Global transcriptional analysis of Streptococcus mutans sugar transporters using microarrays. J Bacteriol 2007;189:5049-59.

16- Russell JI, MacFarlane TW, Aitchison TC, Stephen $\mathrm{KW}$, Burchell CK. Caries prevalence and microbiological and salivary caries activity tests in Scottish adolescents. Community Dentistry and Oral Epidemiology 1990;18:120-5.

17- Kuramitsu HK, Wang BY. The whole is greater than the sum of its parts: dental plaque bacterial interactions can affect the virulence properties of cariogenic Streptococcus mutans. Am J Dent 2011;24:153-4.

18- Camling E, Emilson CG. Results with the caries activity test" Cariostat" compared to prevalence of mutans streptococci and lactobacilli. Swed Dent J 1989;13:125-30.

19- Gao XL, Seneviratne CJ, Lo EC, Chu CH, Samaranayake LP. Novel and conventional assays in determining abundance of Streptococcus mutans in saliva. Int J Paediatr Dent 2012;22:363-8.

20- Thomson Wm. The epidemiology of oral diseases in older adults. Geredontology 2014;31 (Suppl 1): 9-16.

21- ME Sarı, E Kalyoncuoğlu, S Çankaya. Fiziksel engelli çocukların ağız ve diş sağlığı yönünden değerlendirilmesi. Atatürk Üniv. Diş Hek. Fak. Derg 2012;1:7-13.
22- MacEntee MI, Wyatt CCL, McBride BC. Longitudinal study of caries and cariogenic bacteria in an elderly disabled population. Community Dent Oral Epidemiol 1990;18:149-52.

23- O Köse, A Dilsiz, T Arabacı. Görme Engelli Bireylerde Ağız Sağlığı. Atatürk Üniv Diş Hek Fak Derg 2014;8:56-60.

24- Nordenram G. Changes in oral status and dental treatment in long term hospital inmates in Stockholm from 1988 to 1990 . Swed Dent J 1993; 17:43:8.

25- Rodrigues E, Laranjeira N, Nunes G, Roque-Ramos L, Vieira A, Fonseca J. Are cariogenic bacteria the major risk factor to dental caries in patients with ulcerative colits? Arq Gastroenterol 2019: 13; 56:118-23.

26- Latti BR, Kalburge JV, Birajdar SB, Latti RG. Evaluation of relationship between dental caries, diabetes mellitus and oral microbiota in diabetics. J Oral Maxillofac Pathol 2018;2:282.

27- Venkatesh Babu NS, Bhanushali PV. Evaluation and association of serum iron and ferritin levels in children with dental caries. J Indian Soc Pedod Prev Dent 2017;35:106-9.

28- Otomo-Corgel J1, Pucher JJ, Rethman MP, Reynolds MA. State of the science: chronic periodontitis and systemic health. J Evid Based Dent Pract 2012;12(Suppl 3):S20-8.

29- Linden GJ, Lyons A, Scannapieco FA. Periodontal systemicassociations: review of the evidence. J Clin Periodontol 2013;40(Suppl 14):S8-19.

30- da Silva JL, de O El Kadre GD, Kudo GA, Santiago JF Junior, Saraiva PP. Oral Health of Patients Hospitalized in the Intensive Care Unit. J Contemp Dent Pract 2016;17:125-9.

31- Rai T, Ym K, Rao A, P AN, Natarajan S, Joseph RM. Evaluation of the effectiveness of a custommade toothbrush in maintaining oral hygiene and gingival health in cerebral palsy patients. Spec Care Dentist 2018;38:367-72.

32- Marsh PD, Devine DA. How is the development of dental biofilms influenced by the host? J Clin Periodontol 2011;38(Suppl 11):S28-35.

33- Akcali A, Huck O, Tenenbaum H, Davideau JL, Buduneli N. Periodontal diseases and stress: a brief review. J Oral Rehabil 2013;40:60-8.

34- Munro $C L$, Grap MJ. Oral health and care in the intensive care unit: state of the science. Am J Crit Care 2004;13:25-34. 
35- da Cruz MK, Morais TM, Trevisani DM. Clinical assessment of the oral cavity of patients hospitalized in an intensive care unit of an emergency hospital. Rev Bras Ter Intensiva 2014; 26:379-83.

36- S Offenbacher, V Katz, G Fertik, J Collins, D Boyd, G Maynor, R McKaig, J Beck. Periodontal infection as a possible risk factor for preterm low birth weight. J Periodontol 1996;67:1103-13.

37- Grossi SG, Genco RJ. Periodontal disease and diabetes mellitus: a two-way relationship. Ann Periodontol 1998;3:51-61.

38- Beck J, Garcia R, Heiss G, Vokonas PS, Offenbacher S. Periodontal disease and cardiovascular disease. J Periodontol 1996; 67: 1123-37.

39- Mercado F, Marshall RI, Klestov AC, Bartold PM. Is there a relationship between rheumatoid arthritis and periodontal disease? J Clin Periodontol 2000; 27: 267-72.

40- Hayes C, Sparrow D, Cohen M, Vokonas PS, Garcia RI. The association between alveolar bone loss and pulmonary function: the VA Dental Longitudinal Study. Ann Periodontol 1998;3:257-61.

41- García-Azorín D, Farid-Zahran M, GutiérrezSánchez M, González-García MN, Guerrero $A L$, Porta-Etessam J. Tension-type headache in the Emergency Department Diagnosis and misdiagnosis: The TEDDi study. Sci Rep 2020; 12; 10:2446.

42- Reyes AJ, Ramcharan K, Maharaj R. Chronic migraine headache and multiple dental pathologies causing cranial pain for 35 years: the neurodental nexus. BMJ Case Rep 2019;20 pii: e230248.

43- La Touche R, Paris-Alemany A, Gil-Martínez A, Pardo-Montero J, Angulo-Díaz-Parreño, FernándezCarnero J. Masticatory sensory-motor changes after an experimental chewing test influenced by pain catastrophizing and neck-pain-related disability in patients with headache attributed to temporomandibular disorders. J Headache Pain 2015;5:16:20.

44- El-Rabbany M, Zaghlol N, Bhandari M, Azarpazhooh A. Prophylactic oral health procedures to prevent hospital-acquired and ventilator-associated pneumonia: a systematic review. Int J Nurs Stud 2015;52:452-64.

45- Okgün AA, Demir KF. Ventilatör ilişkili pnömoninin önlenmesi: Bakım paketi yaklaşımı. İzmir Üniversitesi Tıp Dergisi 2015;3:38-47.
46- Davies GM, Davies RM. Delivering better oral health-an evidence-based toolkit for prevention: a review. Dent Update 2008;35:460-2, 464.

\section{Sorumlu Yazarın Yazışma Adresi Zeliha Gonca Bek Kürklü}

Çukurova Üniversitesi Diş Hekimliği Fakültesi Gültepe Mah, 01250 Sarıçam/Adana

İş tel: 03223387330 | Dahili: 1131

GSM: 05334500892

e-posta: goncabek@mynet.com 